\title{
Examination of Phytochemicals, Antioxidant and Antibacterial Activity of Hemigraphisalternate
}

\author{
S. Agneeswari", M. Jansi
}

\begin{abstract}
Plants as the source of medicine plays avital role in the health service around world. Hemigraphis alternata (Acanthaceae), exotic plants adapt to India, is versatile tropical lower-creeping perennial herbs that reachheight of $15-30$ centimeters. The matured leaf of Hemigraphis alternata was collected from Kurunthankode, Kanyakumari district. Phytochemical screening of the H.alternata revealed the presence of some phytoconstituents such as carbohydrate, protein, alkaloid, flavonoid, saponin, terpenoid and tannin. Previous report shows that H.coloratacontains similar compounds like saponins, flavonoids and terpenoids. The antioxidant property of H.alternata extract were compared with standard ascorbic acid. The ethanolic extract of H.alternata leaf exhibit good scavenging activity with dose dependent manner. Antimicrobial activities of H.alternata leaf extract show the ethanol extract has the maximum activity against bacteria and fungi. This study revealed the presence of different Phytochemical, antioxidant and antibacterial activities of plant H.alternataand can be suggested that the bioactive components are promising natural antimicrobial agents.
\end{abstract}

Keywords: H.alternata, antioxidant, antibacterial, medicine.

\section{INTRODUCTION}

Plant as source of medicines play an vital role in health service around world[1]. Hemigraphis, an exotic plant adaptin India, is a tropicalversatile, lower-creeping perennial herb that reach height of 15 - 30 centimeters. In Kerala, plant is also called as 'murianpachaor'murikootti'because of its fair good potency to heal wound. Hemigraphis mean 'half writing' because filaments of outer stamen bears brush[2]. The plant have different names like Metal leaf,Aluminiumemetaryplant,Red flame Ivy, Waffle plants, Java Ivy etc. H. alternata is known for its folk medicinal potency that plant has good wound healing activities[3] and it can cure anemia [4]. the leaftraditionally aretaken for gall stone, highlevelsof menstruations and as contraceptives.H.alternatafor treating hemorrhoids, diarrhoea, excessive menstruations andkin disease [5]. The antidiabetics property of $H$. alternata were found for 1 st time by using Wistar rat and Swiss albino mices byGatathri et al.[4]. Medicinal plantcan be focused by many workerwho found therapeutic benefitof traditional system of medicines in wound repairs $[6,7]$. The medical property of plant differ in

Revised Manuscript Received on December 15, 2019

* Correspondence Author

*S. Agneeswari, Department of Zoology, Vivekananda College, Agasteeswaram, Kanyakumari,

M. Jansi, Department of Zoology, S.T. Hindu College, Nagercoil.

Corresponding Author mail: s.agneeswari@yahoo.com varying plant like roots, rhizomes, stems, flowers,eaf, fruits or seeds. So it is very essential to analyse pharmacognostic study in plants [8]. Some of the examples for pharmacognostic studies are Tephrosia purpurea root [9]; Ferulasumbul root [10]; rhizome of Smilax domingensis [11]; Mangiferaindica leaf [12]; Diplaziumesculentum leaf [13]; Cissusquadrangularis stem [14]; Argyreiapilosa stem [15]; fruit of Helicteresisora[16]; flowers of Woodfordiafruticosa [17] and Aervalanata[18].The antimicrobial action of plant on microorganisms are due to the presence of certain antimicrobial agents such as alkaloids, flavonoids, volatile oils, gums, tannins, saponins, steroids and some other secondary metabolites present in the plants [19-21].Therefore, the studyobjective was to assess pharmacological potentials like phytochemical constituents, antioxidant and antibacterial of the crude and solvent extracts of H.alternataleaves.

\section{MATERIALS AND METHODS}

\section{Sample collection and processing}

The matured leaves of Hemigraphis alternata was collected from Kurunthankode of Kanyakumari district. The plant was taxonomically identified by Professor Dr. P. Nagendra Prasad, Head, Department of Biotechnology, Sri Paramakalyani College, Alwarkurichi, Tirunelveli. Freshly collected $H$. alternata leaves were washed in running tap water washed for 3 minutes. Then the plant parts were rinsed with sterile distilled water thoroughly to remove residues. Excess moisture was removed from the sterilized leaves .Then they were subjected to solvent and crude extraction.

\section{Preparation of crude and solvent Extracts}

About $10 \mathrm{~g}$ fresh leaves of $H$. alternate was macerated in mortarandpestle at room temperature and then filtered by muslin cloths under aseptic condition and the filtrate crude sample was collected in fresh sterilized glass tubes and stored at $4{ }^{\circ} \mathrm{C}$ until use [22].Fresh leaves were cut into small pieces and to $5 \mathrm{~g}$ of leaves, $10 \mathrm{ml}$ of solvent like Ethanol,Petroleum Ether and Aqueous were added separately and grounded with motor and pestle. The extracts were boiled at $60^{\circ} \mathrm{C}$ for 3 hours, kept overnight at $37^{\circ} \mathrm{C}$ and then filterwith Whatman No. 1 filter papers. The extracts were dried and stored at $4^{\circ} \mathrm{C}$.

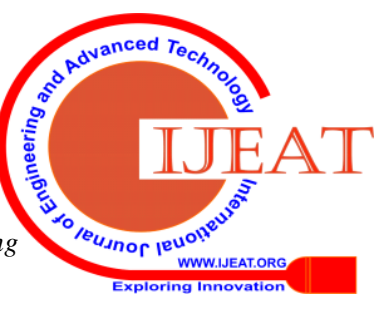




\section{Examination of Phytochemicals, Antioxidant and Antibacterial Activity of Hemigraphisalternate}

\section{Qualitative Phytochemical analysis}

Phytochemical screening of leaf extracts of H.alternata subjected to qualitative phytochemical test for the presence of various classes of active chemical constitutes such as carbohydrate, protein, aminoacid, steroids, saponins, tannin, terpenoid, glycosides, alkaloid, flavanoid and phenol using standard procedure of Mukherjee[23].

\section{Quantification of phytoconstituents}

Phytoconstituents were estimated by various methods like carbohydrate [24], protein [25], saponins, alkaloid, flavonoid [26], tannin[27] and terpenoid [28].

\section{Antioxidant activity determination of Ferrous ion chelating abilities}

The ferrous ion chelating potentials of extract was analysed by Dinis et al.[29] methods. The reaction mixtures contained 1.0 milli litre ofdifferent concentration of extract (2-10 $\mathrm{mg} / \mathrm{ml}$ ) and 0.05 milli litre of $2 \mathrm{mM} \mathrm{FeCl}_{3}$. The reactions were by adding $0.2 \mathrm{ml}$ of $5 \mathrm{mM}$ ferrozine. The reaction mixtures were taken vigorously and left standing at room temperatures for 10 minuteand absorbances of reaction mixtures were measured at $562 \mathrm{~nm}$ against blank. A lowabsorbance of reaction mixtures indicate high ferrous ion chelating abilities. The control contain all reagents except samples. Ascorbic acid was used as standard for comparisons.

$\%$ Inhibition $=[($ Control- Test $) /$ control $] \times 100$

\section{Nitric oxide radical scavenging assays}

Nitric oxides from sodium nitroprusside interact with oxygen for producing nitrite ions which was measured by Griess reactions. This assay was done by proceduredin Green et al.[30]. The reaction mixtures containing $3 \mathrm{ml}$ of $10 \mathrm{mM}$ sodium nitroprussides in phosphates buffered salines ( $\mathrm{pH} 7.4$ ) and different concentrations of $(2-10 \mathrm{mg} / \mathrm{ml})$ extract. The resulting solutions were then incubated at $25^{\circ} \mathrm{C}$ for 60 minute. To incubated samples $5.0 \mathrm{ml}$ of Griess reagents $(1 \%$ sulphanilamides, $0.1 \%$ NEDD in $2 \% \mathrm{H}_{3} \mathrm{PO}_{4}$ ) were added and absorbances of chromophore formed was measured at $546 \mathrm{~nm}$ against a reagent blank. Percentage inhibition of the nitrite ions generated is observed. The standard ascorbic acid and BHT was used for comparison. The free radical scavenging activity was determined by evaluating $\%$ inhibition as above. Antibacterial activity

Antibacterial activity of leaf extracts of $H$. alternata was determined by using agar disc diffusion method on Muller Hinton agar (MHA) medium [31]. The bacterial strains were first cultured in a nutrient broth for 18 hours prior to use. Test organisms used are five Gram positive, five Gram negative and five fungi. $25 \mu \mathrm{l}$ of sample with $100 \mu \mathrm{g}$ concentration is used as test sample. Streptomycin $25 \mu \mathrm{g}$ was used as positive control and sterile disc (Hi-media) was used as negative control.

\section{RESULTS}

\section{Phytochemical Screening}

The phytochemical screening of H.alternata showed the presence of carbohydrate protein, alkaloid, flavonoid, saponin, tannin and terpenoid (Table 1).

Table 1: Phytochemical analysis of H.alternata leaf extracts

\begin{tabular}{|c|c|c|c|}
\hline TEST NAME & Ethanol & Petroleum ether & Aqueous \\
\hline Carbohydrate & + & - & + \\
\hline Protein & - & + & - \\
\hline Alkaloid & - & - & + \\
\hline Flavonoid & + & - & - \\
\hline Glycoside & - & - & - \\
\hline Steroid & - & - & - \\
\hline Saponins & + & + & - \\
\hline Phenol & - & - & - \\
\hline Tannin & + & + & - \\
\hline Terpenoids & + & - & + \\
\hline
\end{tabular}

\section{Quantitative estimation of phytoconstituents}

The quantitative estimation of different extract were carried out and was tabulated in Table 2. Ethanol extract of leaves shows the presence of $55.6 \mathrm{mg} / \mathrm{G}$ of flavonoids and $18.5 \mathrm{mg} / \mathrm{G}$ of saponin. Maximum $67.5 \mathrm{mg} / \mathrm{G}$ of carbohydrate and $52.1 \mathrm{mg} / \mathrm{G}$ of terpenoid. Whereas, minimum amount of tannin $12.1 \mathrm{mg} / \mathrm{G}$. Petroleum ether contains $25.3 \mathrm{mg} / \mathrm{G}$ of protein and $9.3 \mathrm{mg} / \mathrm{G}$ of saponin. The aqueous extract contains maximum $53.8 \mathrm{mg} / \mathrm{G}$ of alkaloid, $36.9 \mathrm{mg} / \mathrm{G}$ of carbohydrate, $48 \mathrm{mg} / \mathrm{G}$ of terpenoid and $26.1 \mathrm{mg} / \mathrm{G}$ of tannin.

Table 2: Quantitative estimation of phytoconstituents in H. alternata

\begin{tabular}{|l|l|l|l|}
\hline \multicolumn{1}{|c|}{ Test } & \multicolumn{1}{|c|}{ Ethanol } & Petroleum ether & \multicolumn{1}{|c|}{ Aqueous } \\
\hline Carbohydrate mg/G & 67.5 & - & 36.9 \\
\hline Protein mg/G & - & 25.3 & - \\
\hline Alkaloidmg/G & - & - & 53.8 \\
\hline Flavanoidmg/G & 55.6 & - & - \\
\hline Tannin mg/G & 12.1 & - & 26.1 \\
\hline Saponin mg/G & 18.5 & 9.3 & - \\
\hline Terpenoidmg/G & 52.1 & - & 48 \\
\hline
\end{tabular}

\section{Antioxidant activity}

Nitric oxide scavenging assay of all extracts was determined at 3 different concentrations $(25,50$ and $100 \mu \mathrm{g} / \mathrm{ml})$ and results of scavenging efficiency of extracts are depicted in Table 3, 4 and Figure1, 2 .

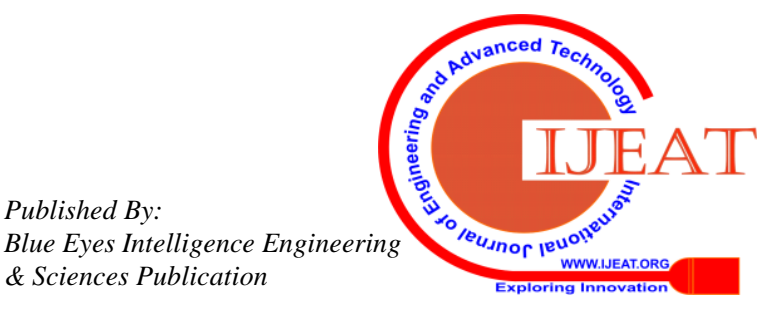


The results showed that scavenging is higher of $65.8 \%$ by the higher concentration of ethanol extract likewise the ferrous iron chelating assay was measured with three concentration of all extracts. The ferrous iron chelating activity increasewith increased concentrations. The chelating power was $56.9 \%$ by ethanol extract.

Table 3: Nitric Oxide Scavenging Activity of H.alternata leaf extracts

\begin{tabular}{|l|l|l|l|l|}
\hline \multicolumn{5}{|c|}{ Percentage of Nitric oxide scavenged (\%) } \\
\hline $\begin{array}{l}\text { Concentra } \\
\text { tion }\end{array}$ & Ethanol & $\begin{array}{l}\text { Petroleum } \\
\text { ether }\end{array}$ & Aqueous & $\begin{array}{l}\text { Standard } \\
\text { (Ascorbic } \\
\text { Acid) }\end{array}$ \\
\hline $25 \mu \mathrm{g} / \mathrm{ml}$ & 33.1 & 21.4 & 31.6 & 56.3 \\
\hline $50 \mu \mathrm{g} / \mathrm{ml}$ & 48.1 & 34.9 & 45.4 & 69.5 \\
\hline $100 \mu \mathrm{g} / \mathrm{ml}$ & 65.8 & 41.8 & 54.6 & 92.5 \\
\hline
\end{tabular}

Table 4: Ferrous Ion Chelating Activity of H.alternata leaf extracts

\begin{tabular}{|l|l|l|l|l|}
\hline \multicolumn{5}{|c|}{ Percentage of Ferrous Ion Chelated(\%) } \\
\hline $\begin{array}{l}\text { Concentra } \\
\text { tion }\end{array}$ & Ethanol & $\begin{array}{l}\text { Petroleum } \\
\text { ether }\end{array}$ & Aqueous & $\begin{array}{l}\text { Standard } \\
\text { (GallicAcid) }\end{array}$ \\
\hline $25 \mu \mathrm{g} / \mathrm{ml}$ & 25.3 & 15.5 & 22.4 & 55.4 \\
\hline $50 \mu \mathrm{g} / \mathrm{ml}$ & 45.8 & 36.1 & 41 & 74.9 \\
\hline $100 \mu \mathrm{g} / \mathrm{ml}$ & 56.9 & 47.5 & 53 & 93.4 \\
\hline
\end{tabular}

Antimicrobial activity of H.alternata.

H.alternata extracts exhibited variable inhibitory response against pathogenic bacteria and fungi. Here ethanol extract shows inhibition against most of the pathogens. Maximum inhibition zone of $38 \mathrm{~mm}$ was observed against Staphylococcus aureus and $34 \mathrm{~mm}$ against Proteus mirabilis. Antifungal activities of ethanol extracts of leaf shows $22 \mathrm{~mm}$ zone of inhibition against Pencillium notatum and Candida albicans. The aqueous extract shows 18 millimolar zones of inhibitions against Proteus vulgaris and moderate activity was recorded for other organisms, whereas petroleum ether extracts show negative results all bacteria and fungi (Table 5, 6 and Figure 3, 4 and 5).
Table 5: Antibacterial activity of H.alternata leaves extract against bacteria.

\begin{tabular}{|l|c|c|c|c|c|c|c|c|c|c|}
\hline \multirow{2}{*}{$\begin{array}{c}\text { Sam } \\
\text { ples }\end{array}$} & \multicolumn{7}{|c|}{ Strains } \\
\cline { 2 - 12 } & $\begin{array}{c}\text { S. } \\
\text { aureus }\end{array}$ & $\begin{array}{c}\text { B. } \\
\text { subtilis }\end{array}$ & $\begin{array}{c}\text { S. } \\
\text { mutans }\end{array}$ & $\begin{array}{c}\text { L. } \\
\text { bacillus }\end{array}$ & $\begin{array}{c}\text { E. } \\
\text { faecalis }\end{array}$ & E. coli & $\begin{array}{c}\text { K. } \\
\text { pneum } \\
\text { oniae }\end{array}$ & $\begin{array}{c}\text { P. } \\
\text { mirabilis }\end{array}$ & $\begin{array}{c}\text { P. } \\
\text { aeruginosa }\end{array}$ & $\begin{array}{c}\text { P. } \\
\text { vulgaris }\end{array}$ \\
\hline PE & - & - & - & - & - & - & - & - & - & - \\
\hline Aq & 10 & 10 & 10 & 10 & 10 & 9 & 11 & 12 & 9 & 18 \\
\hline E & 38 & 26 & 12 & 23 & 13 & 24 & 31 & 34 & 22 & 24 \\
\hline PC & 19 & 23 & 17 & 14 & 22 & 18 & 21 & 19 & 20 & 23 \\
\hline NC & - & - & - & - & - & - & - & - & - & - \\
\hline
\end{tabular}

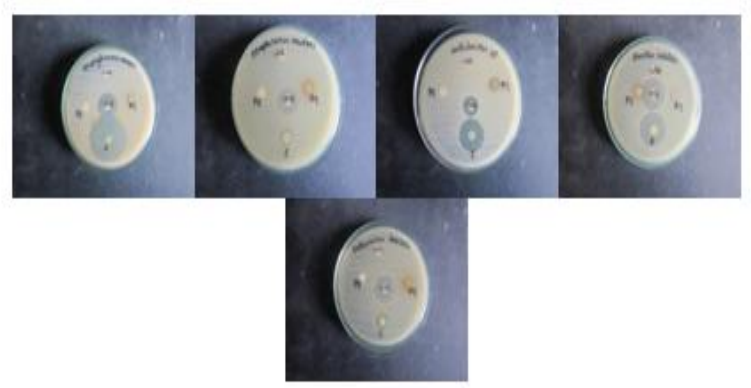

Figure 3: Antibacterial activity of $\mathrm{H}$. alternata leaf extract against Gram positive bacteria

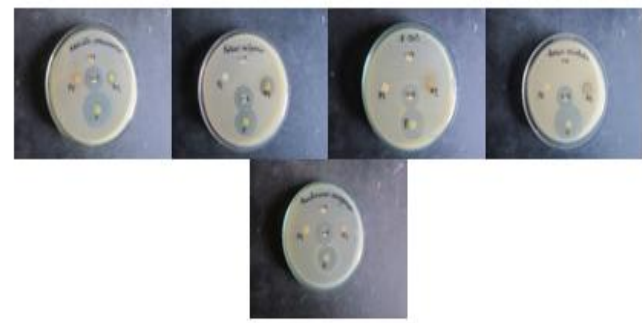

Figure 4: Antibacterial activity of $\mathbf{H}$. alternata leaf extracts against Gram negative bacteria.

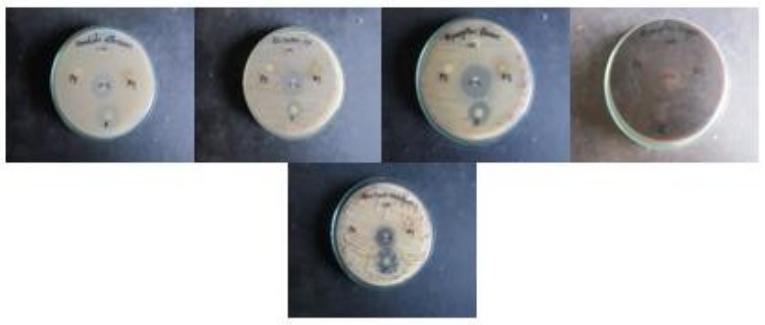

Figure 5: Antibacterial activity of H. alternata leaf extracts against Gram negative bacteria. 
Table 6:Antifungal activities of $H$. alternata leaf extract against bacteria.

\begin{tabular}{|l|c|c|c|c|c|}
\hline \multirow{2}{*}{ Samples } & \multicolumn{5}{|c|}{ Strains } \\
\cline { 2 - 6 } & $\begin{array}{c}\text { Aspergillus } \\
\text { flavus }\end{array}$ & $\begin{array}{c}\text { Aspergillus } \\
\text { niger }\end{array}$ & $\begin{array}{c}\text { Pencillum } \\
\text { notatum sp }\end{array}$ & $\begin{array}{c}\text { Rhizopus } \\
\text { sp }\end{array}$ & $\begin{array}{c}\text { Candida } \\
\text { albicans }\end{array}$ \\
\hline PE & - & - & - & - & - \\
\hline Aq & 9 & - & - & 10 & 9 \\
\hline E & 17 & - & 22 & 13 & 22 \\
\hline$P C$ & 22 & 14 & 17 & 17 & 21 \\
\hline NC & - & - & - & - & - \\
\hline
\end{tabular}

\section{DISCUSSION}

Phytochemical screening of the H.alternata revealed the presence of some phytoconstituents such as carbohydrate, protein, alkaloid, flavonoid, saponin, terpenoid and tannin. Previous report shows that H.coloratacontains similar compounds like saponins, flavonoids and terpenoids [32]. The quantification of phytoconstituents revealed that ethanol extracts contains maximum amount of constituents like carbohydrate, flavonoid and terpenoid. It is supported by report of Priyanka et al.[33] that the ethanol extract of leaves shows the presence of steroid, proteins, amino acids, tannin, coumarins, alkaloids, diterpenes, phenol, tannin and flavonoids. Flavonoids are reported to possess many useful properties, including antiinflammatory, antimicrobial, enzyme inhibition, oestrogenic, antiallergic, antioxidant and anti-tumour activity. Plant contains polyphenolic compounds like flavonoids and they are common in leaves, woody parts, stem, bark and flowering tissues and they prevent the plant with defense against infection and injury [34].

The antioxidant property of H.alternata extract were compared with standard ascorbic acid. The ethanolic extract of H.alternata leaf exhibit good scavenging activity with dose dependent manner. Some effect was noted with ferrous ion activity of the ethanolic extract $56.9 \%$ in higher concentration and $65.8 \%$ in nitric oxide scavenging. Antioxidants provide protection to living organisms from damages caused by uncontrolled productions of reactive oxygen specieandconcomitant lipid peroxidations, proteins damages and DNA strand breakages [35].Some phytoconstituent in leaves extract act as chelating agent. Phenolic compound are efficient in hydrogen donors which makethemgood antioxidants. The phenolic acidlikecinnamate, chlorogenate,coumarates, gallates and ferulates in plant act as pro-oxidantand exhibitfree radical scavenging activities [36]. Antimicrobial activities of H.alternata leaf extract shows the ethanol extract has the maximum activity against bacteria and fungi. Zone of inhibition against S.aureus is more than positive control as it contains good antimicrobial agent. Benzene extracts of H.colorata leafshow its activities against Streptococcus aureus and Acinetobacterspecieresponsible for activities. Antimicrobial activity of herbs is due to variety of secondary metabolites like phenols, unsaturated sterols, triterpenes saponins and phenolic terpenoids[38]. Therefore the phytoconstituents present in the leaf extract of H.alternatais responsible for the antimicrobial and antioxidant property.

\section{CONCLUSION}

This study analyse the presence of different phytochemical, antioxidant and antibacterial activities of plant H.alternataand can be suggested that the bioactive components are promising natural antimicrobial agents. Literature survey also showed that the plant has applications in both traditional and modern medical practices. Further, extensive studies are under process in identify and characterize the bioactive compounds responsible for antioxidant and antimicrobial activity.

\section{REFERENCES}

1. G. Thomson, Further consideration of Asian medicinal plants in treating common chronic diseases in the West, Journal of Medicinal Plants Research, 4 (2010) 125-130.

2. D. Gledhill, The Names of Plants., Edn 4, Cambridge University Press, New York, , (2008) 195.

3. V. Silja, Varma, KS \& Mohanan, K, Ethnomedicinal plant knowledge of the Mullu kuruma tribe of Wayanad., Indian Journal of Traditional Knowledge, 7 (2008) 604-612.

4. V. Gayathri, Lekshmi, P \& Padmanabhan, RN, Anti-Diabetes and Hypoglycaemic properties of Hemigraphiscolorata in Rats, International Journal of Pharmacy and Pharmaceutical Sciences, 4 (2012) 224- 328.

5. P. Mallikharjuna, Rajanna, LN, Seetharam, YN \& Sharanabasappa, GK, Phytochemical studies of Strychnos potatorum L.F, A medicinal plant E-jour Chem, 4 (2007) 510-518.

6. S. Nayak, Nalabothu, P, Sandiford, S, Bhogadi, V \& Adogw, A Evaluation of Wound healing activity of Allamanda cathartica. L. and Laurus nobilis. L. extracts on rats. , BioMed Central Complementary and Alternative Medicine, 6 (2006) 12.

7. B. Rathi, Bodhankar, SL \& Baheti, AM, Evaluation of aqueous leaves extract of Moringa oleifera Linn for wound healing in albino rats, Indian J Exp Biol., 44 (2006) 898-901.

8. S. Chanda, Importance of pharmacognostic study of medicinal plants: An overview., J Phcog Phytochem, 2 (2014) 69-73.

9. R. Shah, Shah, R \& Chanda, S, Pharmacognostical and preliminary phytochemical investigation of Tephrosia purpurea (Linn.) Pers. root from Gujarat region, Int J Pharmaceutic Res., 3 (2011) 49-52.

10. S. Batra, Kumar, A \& Sharma, A, Pharmacognostic and phytochemical studies on Ferula sumbul Hook. Roots, J Phcog Phytochem, 4 (2017) 965-968.

11. J. Yaque, Monan, M, Cuéllar, A, de Armas, T, Gómez, E \& Dopico, E, Pharmacognostic and phytochemical studies of Smilax domingensis Willd. in Cuba., Am J Plant Sci., 8 (2017) 1462-1470.

12. K.C. Rakholiya, S, Pharmacognostic, physicochemical and phytochemical investigation of Mangifera indica L. var. Kesar leaf. , Asian Pac J Trop Biomed., 2 (2012) S680-S684.

13. G. Dash, Khadidi, SKJ \& Shamsuddin, AF, Pharmacognostic studies on Diplazium esculentum (Retz.) Sw., Der Pharm Lett., 9 (2017) 113-120.

14. K. Nagani, Kevalia, J \& Chanda, S, Pharmacognostical and phytochemical evaluation of stem of Cissus quadrangularis L, Int J Pharmaceutic Sci Res., 2 (2011) 2856-2862.

15. D. Prasanth, Srinivasa Rao, A \& Rajendra Prasad, Y, Pharmacognostic study of Argyreia pilosa stem., Res J Phcog. , 4 (2017) 23-31.

16. P.B. Kanthale, S, Pharmacognostic study of Helicteres isora L. , Pharmaceut and Biol Evaluat, 4 (2017) 47-51. 
17. Y. Baravalia, Nagani, K \& Chanda, S, Evaluation of pharmacognostic and physicochemical parameters of Woodfordia fruticosa Kurz. Flowers. , Phcog J, 2 (2011) 13-18.

18. N. Silvia, Rajeswari, CH, Mounica, D, Manasa, R \& Prasanth DSNBK, Pharmacognostic and phytochemical studies on flowers of Aerva lanata [L.] Juss. ex. Schult. , Phcog J, 6 (2014) 29-32.

19. S. Kochlar, Tropical Crops. In: A Textbook of Economic Botany. , Macmillan Publishers Ltd, London and Basingstoke. , (1986) 21-25, 33-34.

20. E. Sofowora, Medicinal Plants and Traditional Medicine in Africa., John Wiley and sons, U.S.A., (1982) 10-40.

21. J. Oyagade, Awotoye, OO, Adewumi, JT \& Thorpe, HT, Antimicrobial Activities of Some Nigerian Medicinal Plants. Screening for Antimicrobial Activity. , Bioscience Research Communication, 11 (1999) 193-197.

22. P. Goyal, Khanna, A, Chauhan, A, Chauhan, G \& Kaushik, P, In vitro evaluation of crude extracts of Catharanthus roseus for potential antibacterial activity, International Journal of Green Pharmacy, 2 (2008) 176-181.

23. P.c.o.h.d. Mukherjee, business horizons pharmaceutical publishers, , Quality control of herbal drugs, business horizons pharmaceutical publishers,. 356 - 358., New Delhi, 356 - 358. (2002).

24. J. Roe, The determination of sugar in blood and spinal fluid with anthrone reagent, The Journal of biological chemistry, 212 (1955) 335-343.

25. O. Lowry, Rosenberg, NJ, Farr, AL \& Randal, RJ, Protein measurement with the Folin-Phenol reagent, The journal Biological Chemistry, 193 (1951) 265-275.

26. W. Evans, Trease Evans Pharmacognosy, 14th ed., London: WB Saunders Ltd.1966.

27. E. Robert, Method for estimation of tannin in grain sorghum, Agro J, 63 (1971) 511.

28. N. Ghorai, Chakraborty, S, Gucchait, S, Saha, SK \& Biswas, S, Estimation of total Terpenoids concentration in plant tissues using a monoterpene, Linalool as standard reagent., scientific protocols, (2012).

29. T. Dinis, Madeira, VMC \& Almeida, LM, Action of phenolic derivatives (acetaminophen, salicylate, and 5-aminosalicylate) as inhibitors of membrane lipid peroxidation and as peroxyl radical scavengers, Arch Biochem Biophys, 315 (1994) 161-169.

30. L. Green, Wagner, DA, Glogowski, J, Skipper, PL \& Wishnok JS, Analysis of nitrate, nitrite, and [15N]nitrate in biological fluids, Anal Biochem, 126 (1982) 131-138.

31. K. Salah Alhashimi, Khaleel Rashid, I, Ghoson Saleh, S, Alea Abdulhadi, M \& Tara Taher, A, The antimicrobial activity of leaves and callus extracts of Thevetia peruviana In vitro, Journal of Biotechnology Research Center, 7 (2013) 74-80.

32. J. Sheu, Jayakumar, T, Chang, C, Chen, Y, Priya ,S, Ong, E, Chiou, H \& Elizebeth, AR, Pharmacological actions of an ethanolic extracts of the leaves Hemigraphis colorata and Clerodendron phlomoides., Clin Mol Med 4(2012) 1-3.

33. S. Priyanka, Anupama, D, Misna, M, Nisha Jayan, Reshma, J, Reshma, PR, Sana, PA Saranya, KG, Vidya, PV \& Thomas, L, Phytochemical screening and biosynthesis of silver nanoparticles of selected medicinal plants used in Traditional Medicine, Journal of Medicinal Plants Studies, 4 (2016) 01-05.

34. S. Ghosal, Tripathi, VK \& Chauhan, S, Active constituents of Emblica officinalis. Part I. The chemistry and antioxidant effects of two new hydrolysable tannins, emblicanin A and B., Ind J Chem, 35 (1996) 941-948.

35. R. de Sousa, Queiroz, KC, Souza, AC, Gurgueira, SA, Augusto, AC, Miranda, MA, Peppelenbosch, MP, Ferreira, CV \& Aoyama, H, Phosphoprotein levels, MAPK activities and NFKappaB expression are affected by fisetin, Journal of Enzyme Inhib Med Chem, 22 (2007) 439-444.

36. R. Deepak, Renjima, V \& Murugan, K, Antioxidant Potential of Hemigraphis colorata (Blume) H.G.Hallier and Rhinacanthus nasutus (Linn). Kurz, A Search. In Proceedings of the 2007 Kerala Science Congress (03-40), Kannur, Kerala,, (2007) 1-4.

37. V. Anitha, Antonisamy, JM \& Jeeva, S, Anti-bacterial studies on Hemigraphis colorata (Blume) H.G. Hallier and Elephantopus scaber L, Asian Pac J Trop Med 5(A2012) 52-57.

38. T. Fujiwara, Sugishita, EY, Takeda, Y, Shimizu, M, Nomura, T \& Tromita, Y, Further studies on the structures of polysachharides from the bark of Melia azadirachta. , Chemical and Pharmacology Bulletin., 32 (1984) 1385-1391. 